\title{
航海士の夜間視機能の適性について
}

\section{On the Aptitudes of the Night Visual Function of Navigators}

\author{
西部徹 一(学働科学研究所) \\ 千原義 男(航海訓緬所) \\ 福井淡（海技專堙学院）
}

\begin{abstract}
The authors investigated the thresholds of the dark adaptation extending over 146 students of the Marine Technical School and studied the elements to be examined and the testing methods concerning the aptitudes of the night visual function which is required for navigators.
\end{abstract}

\section{1 まえがき}

夜間航海当直中における航海士の見脹能力の良否は、まず第一に航海士の眼の暗順巵の状態に 関係する。眼の暗順応の状態は航海士の暗順応機能の能力や周囲の明るさ或はそれより前に受け た光照射の明るさや照射時間の条件等によつて在不される。

航海士の夜間当直中における暗順応の変化の状沿及びその保護対策についてはその一部を前に 本学会において報告1)した。今回は海技専門学院の学生の暗順応機能の調査結果及び従来の文塥 にもとずいて、暗順応機能の個人差と、更に航海士の夜間視の適性という点について椎討を加光 る。

\section{2 暗順応機能の個人差について}

暗順応機能の個人差を来す原因には、年令の影響、屈折状態、眼球内色素の多少、瞳孔の大き さ等2)があげられている。特に先天的或は後天的に網膜色素の発育が悪い場合には夜盲となる素 質を有するといわれている。

又、栄養特にビタミンAの矢乏、酸素不足、極度の疲労、長時間の不眠、低圧等による身体の 条件の ${ }^{3)}$ 状態によつて、暗順応機能の低下を来すととが確められている。

航海士としての視覚適性という点から考えると、素筫的に夜盲のものは当然除去される必要が あり、又身体の条件の悪い昜合については、それに対する処置がなされる必要がある。てのため には、将来において暗順応機能の評価基準を設是し、その枱查の方法を確立する必琹があるので はないかと考える。

暗順応の経過を模型図によつて示すと図 1 のとおりであり、暗順応が充分完子するまでに恬 


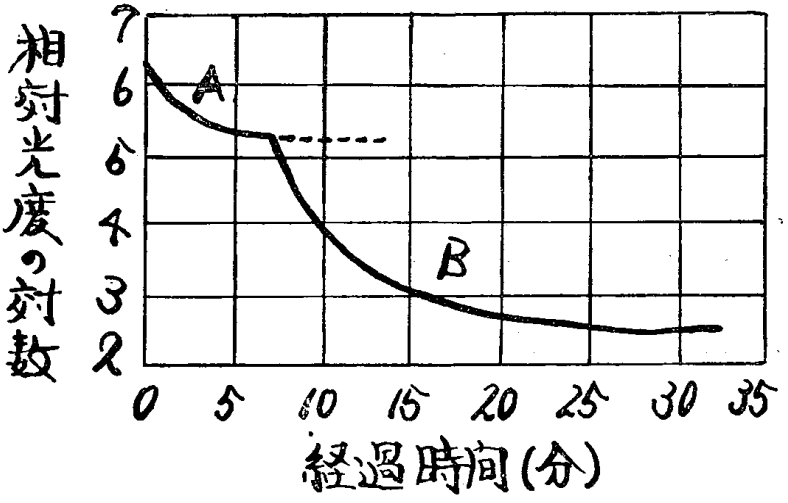

四/、日亶順庆曲線 (模型四)

50～60分を要する。暗順応機能の個人差という のは順応が充分完了した状態における光刺激闘 值（認めることのできる最少の明るさ）の水準 の高低と、暗順応の経過の型の差異という二つ の面において見られる。

正常者の閾值はかなり一定の範团にあるが、

ての範囲外にあるものは異常者とみなされ る。暗順応の経過の型には、閾值の下降（感光 度の増加）の傾向がゆるやかで、終期閾值が比 較的に高いものと、閾值の下降が前者より急で 終期閾值が低いものと二つの型が区別できると

いわれている。

\section{3 海専学生の暗順応機能の分布}

今面の調查においては、充分暗順応を完了した時の光刺激閾梿或は順応の経過を測定するてと は、非常に多くの時間を要し、集団蚞查の場合には不適当なので、暗順応20分経過時における閤 值を試作暗順応計（ナーゲル暗順応計を改良したもの）によつて測定した。

なお、暗順応の経過は暗所に入る前の眼の順応の状態によつて変るので、測走前に15〜20分間

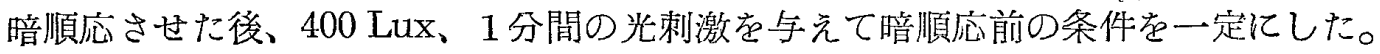

因2，堷顺㐫械能の频度分布

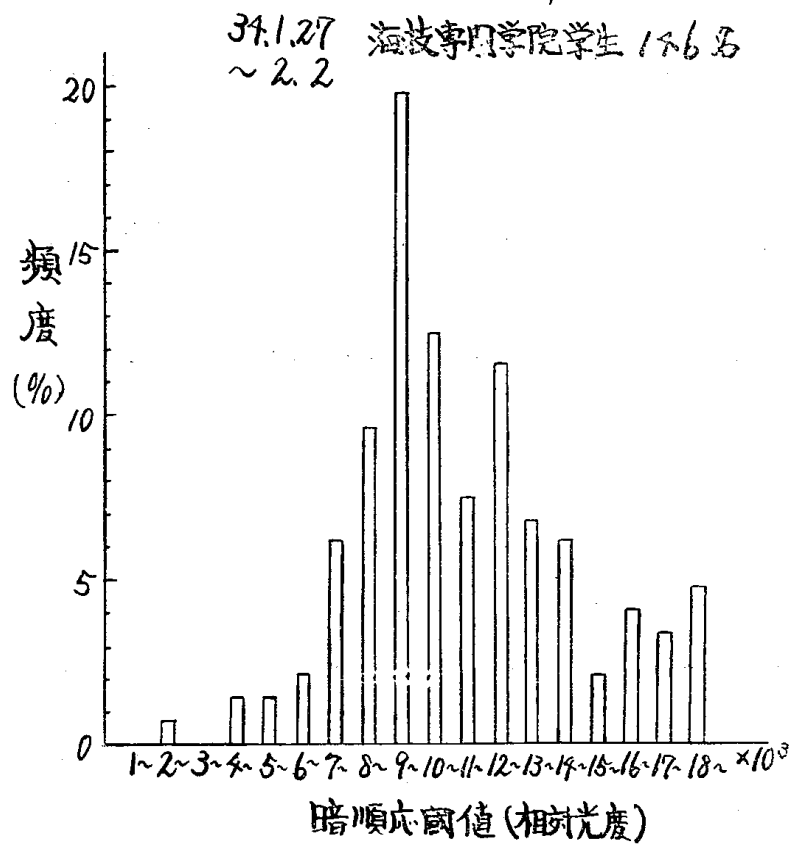

測定人員は 146 名であり、その暗順応機能の 分布を示すと図2のと扔りである。困に見るよ うにほば正規分布をなしている。

ての場合、暗順応20分時における闌镇によつ て、各個人の終期の閾值の優劣が判定できるか どうかということが問題になる。そこで、暗順 応20分になる前に一度閾犆を測定しているので その閾值と20分時の閾直とによつて閾值の下降 速度（每分）を訂算し、その分布を取つてみる と、暗順応20分時における閾值为低いもの程、 その下降速度が大きく、20分時の閾值が高いも の程、前者より下降速度がゆるやかで、既亿順 応を殆んど完了していると思われるものが多く なつている。従つて20分時の閾值によつて終期 閾值の優劣を推定しても間違いないと思われ る。.

図2 の暗順応機能の分布より、標潐偏差によ る評価基準表を作製すると表1のようになる。表において、Eの評価に属するものが、10\%近く いるが、てれらのものの機能はかなり劣つているというととができる。しかし、劣つているとい

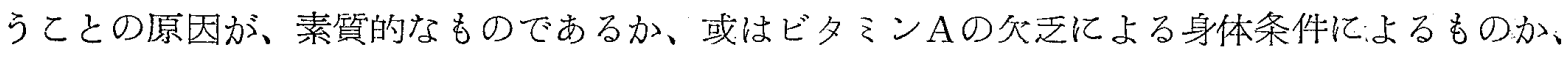
はつきりしたてとがわからないので、暗順応機能が異常であるかどうかという判定はできない。 
表 1 暗順応機能の評価基準表

$\mathrm{M}=11,500 \quad \sigma=3,000$

(400lx 1 分間明順応20分間暗順応時)

\begin{tabular}{|c|c|c|c|c|c|c|}
\hline 評 定 & 単 位 & 相 対 光 度 & 相対光度の対数 & 相対感光度の対数 & $\begin{array}{c}\text { ミリランバート } \\
\text { (n11の対数) }\end{array}$ & $\begin{array}{l}\text { 海輠学生の調查 } \\
\text { 結果 }\end{array}$ \\
\hline A & 1 & 4,000 & 3.60 & 4.40 & $\overline{6} .81$ & 8名 \\
\hline F & 1 & 7,000 & 3.85 & 4.15 & $\overline{5} .06$ & 52名 \\
\hline c & & 10,000 & 4. 00 & 4.00 & $\overline{5} .21$ & 46名 \\
\hline $\mathrm{I}$ & & 13,000 & 4.11 & 3.89 & $\overline{5} .32$ & 22名 \\
\hline E & \{ & $\begin{array}{r}16,000 \\
(20,000)\end{array}$ & $\begin{array}{r}4.20 \\
(4.30)\end{array}$ & $\begin{array}{r}3.80 \\
(3.70)\end{array}$ & $\frac{\overline{5}}{5 .} 41$ & 18名 \\
\hline
\end{tabular}

ての点については、ビタミンAの保有状態との関係や、笑際の作業において必要とする夜間視力 との関係等について蚞討を行い、基常者の判定の規準を明確にする必要がある。

なお、暗順応機能と年令との関係については、文献によると40才を過ぎるとかなり墨くなると いわれているが、今回の調查においては高年令者の例数が少なかつたので、両者の閒の傾向はわ からなかつた。

\section{4 暗順応機能の簡易検查法について}

暗順応機能の集団蚞查を行う場合、暗順応計によつて間值を測定するのが最も確実であるが、 非常に多くの時間を要するので不適当であるというてとは前に述べた。そてで簡易な検查法を検 討するため、次のような検查法も同時に寒施し、喑順応機能との関係を調バた。即ち光刺激を与 えた直後、喑い照度で照した一定の視標（ランドルト氏環又は文字）を見させて、その視標が見 点るようになるまでの時間を測定した。その所要時間の長短によつて暗順応機能との関係を見よ うとするものである。この場合、視標に文字を使つているので空間覚（視力）皇或る程度関係す るものと思われる。

この低照度視標の可読時間の分布を示すと図 3のとおりである。図のようにかたよつた分布 をなしている。この低照度可読時間之暗順応閾 值との相関をとつてみると表 2 のうになる。 相関係数は 0.36 で， $1 \%$ 危険率で有意の相関 及係がなりたつようである。

從つて暗順応機能の渙查の簡易法として、低 照度視標の可読時間を測定する方法を採用する ととができるのではないかと考兊る。

なお、図 3 亿おいて可読不能のものふ（10\%近 く見られるが、てれらのものが出現するのは、 検查の時刻の相違㲹もとずいておうり、表 3 のよ うに、12時から16時頃までの㛟査においては全 然みられないが、17時頃から出てくるようにな

因了、低照度视標可煞時间の顽度分布

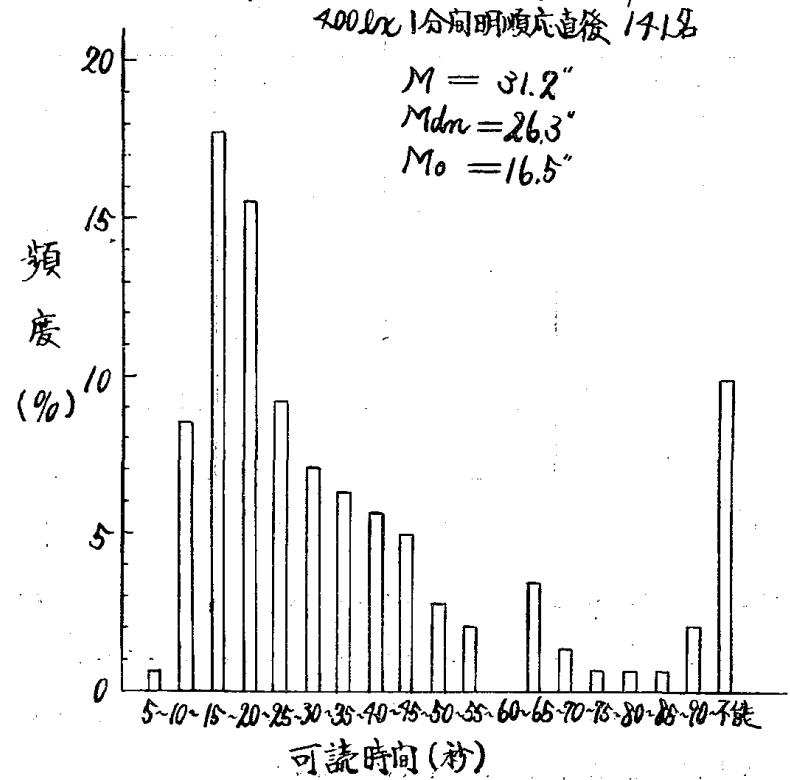


表 2 暗順応機能と低照度視標可読洔間との関係

$$
\text { 相関係数 } \quad r=0.36
$$

測定人員 143 名

(可読不能者は除く)

\begin{tabular}{|c|c|c|c|c|c|c|c|c|c|c|c|}
\hline 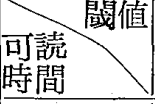 & $\begin{array}{c}1 \times \\
10^{3} \sim\end{array}$ & $\begin{array}{l}3 \times \\
10^{3} \sim\end{array}$ & $\begin{array}{l}5 \times \\
10^{3} \sim\end{array}$ & $\begin{array}{c}7 \times \\
10^{3} \sim\end{array}$ & $\underset{10^{3} \sim}{9 \times}$ & $\begin{array}{l}11 \times \\
10^{3} \sim\end{array}$ & $\begin{array}{l}13 \times \\
10^{3} \sim\end{array}$ & $\begin{array}{l}15 \times \\
10^{3} \sim\end{array}$ & $\begin{array}{l}17 \times \\
10^{3} \sim\end{array}$ & $\begin{array}{l}19 \times \\
10^{3} \sim\end{array}$ & 計 \\
\hline $5^{\prime \prime} \sim$ & & & & & 1 & & & & & & 1 \\
\hline $\begin{array}{l}10^{\prime \prime} \approx \\
15^{\prime \prime} \sim\end{array}$ & & 1 & $\begin{array}{l}2 \\
1\end{array}$ & $\begin{array}{l}7 \\
2\end{array}$ & $\begin{array}{r}3 \\
14\end{array}$ & 4 & 2 & & 2 & & $\begin{array}{l}12 \\
26\end{array}$ \\
\hline $\begin{array}{l}20^{\prime \prime} \sim \\
25^{\prime \prime} \sim\end{array}$ & 1 & 1 & & 4 & $\begin{array}{l}8 \\
3\end{array}$ & $\begin{array}{l}5 \\
4\end{array}$ & 1 & $\begin{array}{l}1 \\
3\end{array}$ & $\begin{array}{l}1 \\
1\end{array}$ & 1 & $\begin{array}{l}21 \\
13\end{array}$ \\
\hline $\begin{array}{l}30^{\prime \prime} \sim \\
35^{\prime \prime} \sim\end{array}$ & & & 1 & $\begin{array}{l}5 \\
1\end{array}$ & $\begin{array}{l}1 \\
4\end{array}$ & $\begin{array}{l}1 \\
2\end{array}$ & $\begin{array}{l}2 \\
2 \\
\end{array}$ & 1 & & & $\begin{array}{l}10 \\
10\end{array}$ \\
\hline $\begin{array}{l}40^{\prime \prime} \sim \\
45^{\prime \prime} \sim\end{array}$ & & & 1 & 1 & $\begin{array}{l}3 \\
2\end{array}$ & $\begin{array}{l}2 \\
1\end{array}$ & 2 & $\begin{array}{l}2 \\
1\end{array}$ & & & $\begin{array}{l}8 \\
7\end{array}$ \\
\hline $\begin{array}{l}50^{\prime \prime} \sim \\
55^{\prime \prime} \sim\end{array}$ & & & & & & $\begin{array}{l}1 \\
1\end{array}$ & $\begin{array}{l}1 \\
1\end{array}$ & & $\begin{array}{l}2 \\
1\end{array}$ & & $\begin{array}{l}4 \\
3\end{array}$ \\
\hline $\begin{array}{l}60^{\prime \prime} \sim \\
65^{\prime \prime} \sim\end{array}$ & & & & 1 & & 1 & 2 & & 1 & & $\begin{array}{l}0 \\
5\end{array}$ \\
\hline $\begin{array}{l}70^{\prime \prime} \sim \\
75^{\prime \prime} \sim\end{array}$ & & & & & & 1 & 1 & & 1 & & $\begin{array}{l}2 \\
1\end{array}$ \\
\hline $\begin{array}{l}80^{\prime \prime} \sim \\
85^{\prime \prime} \sim\end{array}$ & & & & & & & 1 & & 1 & & $\begin{array}{l}1 \\
1\end{array}$ \\
\hline $90^{\prime \prime} \sim 94^{\prime \prime}$ & & & & & 1 & 2 & & & & & 3 \\
\hline 不 ${ }_{\text {計 }}^{\text {能 }}$ & 1 & 2 & 5 & $\begin{array}{r}3 \\
24 \\
\end{array}$ & $\begin{array}{r}6 \\
46 \\
\end{array}$ & $\begin{array}{r}1 \\
26\end{array}$ & $\begin{array}{r}3 \\
18\end{array}$ & $\begin{array}{r}2 \\
10\end{array}$ & 10 & 1 & $\begin{array}{r}15 \\
143\end{array}$ \\
\hline
\end{tabular}

表 3 時刻別の低照度視標可読時間の度数分布

\begin{tabular}{|c|c|c|c|c|c|c|c|c|}
\hline 可読時間 & $\begin{array}{l}12.30 \\
13.30\end{array}$ & $\begin{array}{l}13.30 \\
14.30\end{array}$ & $\begin{array}{l}\text { 14. } 30 \\
15.30\end{array}$ & $\begin{array}{l}15.30 \\
16.30\end{array}$ & $\begin{array}{l}16.30 \\
17.30\end{array}$ & $\begin{array}{l}17.30 \\
18.30\end{array}$ & $\begin{array}{l}18.30 \\
19.30\end{array}$ & 計 \\
\hline $5^{\prime \prime} \sim$ & 1 & & & & & & & 1 \\
\hline $\begin{array}{l}10^{\prime \prime} \sim \\
15^{\prime \prime} \sim\end{array}$ & $\begin{array}{l}5 \\
4 \\
\end{array}$ & 4 & 2 & $\begin{array}{l}3 \\
4 \\
\end{array}$ & $\begin{array}{l}4 \\
8\end{array}$ & 2 & 3 & $\begin{array}{l}12 \\
27\end{array}$ \\
\hline $\begin{array}{l}20^{\prime \prime} \sim \\
25^{\prime \prime} \sim\end{array}$ & $\begin{array}{l}4 \\
3 \\
\end{array}$ & 1 & 1 & $\begin{array}{l}5 \\
5 \\
\end{array}$ & $\begin{array}{l}6 \\
3 \\
\end{array}$ & $\begin{array}{l}2 \\
3 \\
\end{array}$ & 1 & $\begin{array}{l}19 \\
15\end{array}$ \\
\hline $\begin{array}{l}30^{\prime \prime} \sim \\
35^{\prime \prime} \sim\end{array}$ & $\begin{array}{l}1 \\
1\end{array}$ & $\begin{array}{l}2 \\
1\end{array}$ & $\begin{array}{l}1 \\
1\end{array}$ & $\begin{array}{l}2 \\
2\end{array}$ & 2 & $\begin{array}{l}1 \\
2\end{array}$ & $\begin{array}{l}1 \\
3\end{array}$ & $\begin{array}{l}10 \\
10\end{array}$ \\
\hline $\begin{array}{l}40^{\prime \prime} \sim \\
45^{\prime \prime} \sim\end{array}$ & 2 & $\overline{1}$ & & $\begin{array}{l}2 \\
1 \\
\end{array}$ & $\begin{array}{l}1 \\
3 \\
\end{array}$ & $\begin{array}{l}2 \\
1 \\
\end{array}$ & 2 & $\begin{array}{l}8 \\
7 \\
\end{array}$ \\
\hline $\begin{array}{l}50^{\prime \prime} \sim \\
55^{\prime \prime} \sim\end{array}$ & & 1 & & r. & & 2 & $\begin{array}{l}3 \\
1\end{array}$ & $\begin{array}{l}4 \\
3\end{array}$ \\
\hline $\begin{array}{l}60^{\prime \prime} \sim \\
65^{\prime \prime} \sim\end{array}$ & 1 & & & & & & $\begin{array}{l}1 \\
1\end{array}$ & $\begin{array}{l}1 \\
2\end{array}$ \\
\hline $\begin{array}{l}70^{\prime \prime} \sim \\
75^{\prime \prime} \sim\end{array}$ & & & & & & $\begin{array}{l}1 \\
1\end{array}$ & & $\begin{array}{l}1 \\
1\end{array}$ \\
\hline $\begin{array}{l}80^{\prime \prime} \sim \\
85^{\prime \prime} \sim\end{array}$ & & & & & & $\begin{array}{l}1 \\
1\end{array}$ & & $\begin{array}{l}1 \\
1\end{array}$ \\
\hline $\begin{array}{l}90^{\prime \prime} \sim 94^{\prime \prime} \\
\text { 不 }^{\text {能 }}\end{array}$ & & & & 1 & 3 & $\begin{array}{l}2 \\
6 \\
\end{array}$ & 5 & $\begin{array}{r}2 \\
15 \\
\end{array}$ \\
\hline 計 & 22 & 10 & 5 & 25 & 30 & 27 & 21 & 140 \\
\hline 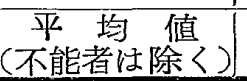 & 24.5 & 29.8 & 26.5 & 26.3 & 28.8 & 41.9 & 42.0 & 31.2 \\
\hline
\end{tabular}

り、18時頃の検查において最も多く出現している。また可読時間の分布の範囲を見ても18時頃に 大きくなつている。即ち18時前後に扔て視標の文字が見えにくくなつているということができ

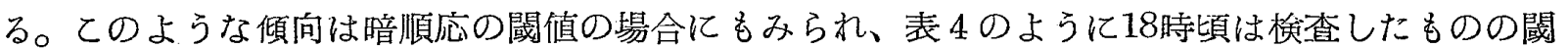
值の平均值が幾分高くなつている。 
表 4. 測定時刻別の暗順応機能度数分有

\begin{tabular}{|c|c|c|c|c|c|c|c|c|}
\hline $\begin{array}{ll} & \text { 測定 } \\
\text { 闌 值 }\end{array}$ & $\begin{array}{l}12.30 \\
13.30\end{array}$ & $\begin{array}{l}13.30 \\
14.30\end{array}$ & $\begin{array}{l}14.30 \\
15.30\end{array}$ & $\begin{array}{l}15.30 \\
16.30\end{array}$ & $\begin{array}{l}16.30 \\
17.30\end{array}$ & $\begin{array}{l}17.30 \\
18.30\end{array}$ & $\begin{array}{l}18.30 \\
19.30\end{array}$ & 計 \\
\hline $1 \times 10^{3} \sim$ & & & & 1 & & . & & 1 \\
\hline $3 \times 10^{3} \sim$ & 1 & & & 1 & & & & 2 \\
\hline $5 \times 10^{3} \sim$ & 1 & 1 & & 3 & & & & 5 \\
\hline $7 \times 10^{3} \sim$ & 5 & 1 & 1 & 4 & 6 & 4 & 2 & 23 \\
\hline $9 \times 10^{3} \sim$ & 7 & 3 & 2 & 14 & 9 & 7 & 5 & 47 \\
\hline $11 \times 10^{3} \sim$ & 7 & 1 & 1 & 2 & 5 & 5 & 7 & 28 \\
\hline $13 \times 10^{3} \sim$ & 4 & 1 & 1 & 3 & 3 & 2 & 5 & 19 \\
\hline $15 \times 10^{3} \sim$ & & & & 3 & 2 & 4 & & 9 \\
\hline $17 \times 10^{3} \sim$ & 1 & 3 & & & 2 & 5 & 1 & 12 \\
\hline 計 & 26 & 1.0 & 5 & 31 & 27 & 27 & 20 & 146 \\
\hline 平均 值 & $10.8 \times 10^{3}$ & $12.1 \times 10^{3}$ & $10.6 \times 10^{3}$ & $1,0.0 \times 10^{3}$ & $11.2 \times 10^{3}$ & $13.1 \times 10^{3}$ & $12.0 \times 10^{3}$ & $11.3 \times 10^{3}$ \\
\hline
\end{tabular}

この理由については、18時頃は電気の需要が多い時間で電压が低下し測定器の条件が変つたた めか、或は暗順応機能が生理的にての時期に悪くなる傾向があるためなのか、はつきりしたてと はわからない。今後更に充分な追試を行う予定である。しかしその理由がいずれであつても、暗 順庒の闇值より夜間視力の関係している低照度視標可読時間の方が、僅かの条件の変化によつて も著しい影響を受けるというととは、夜間における見卧能力及びその個人差というものを考える 場合に重要な問題ではないかと考える。

\section{5 夜間視機能に関する適性について}

夜間視においては今迄に述べた暗順応機能の他に、光感覚時、明度識別闇值、夜間視力、薄暮 視力、暗所における視野等の視機能が関与する。従つててれらの機能のすべてが適性の問題に関 連するわけであるが、実際に適性蚞査 ${ }^{4}$ の項目を選ぶ場合には、作業を行う上において必要とさ れる程度や、それぞれの機能相百の相関及係によつて選定するととになる。機能が相互に独立で あれば、それぞれの項目について検查する必要があり、相関及係があれば、主となる一つの機能 の検查だけ行えば良いというととになる。

そこで暗順応機能、昼聞視力（錐体視力）、薄暮視力（低照度視力、30 Lux 以下の照度）、夜

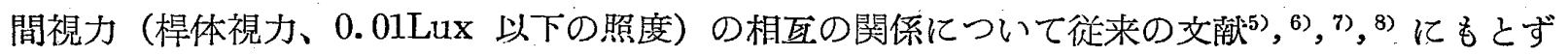
いて検討してみると次のとおりである。

(1) 暗順応機能と各視力との間にはある程度相関々係があといわれ，㡺間視力よりも薄暮視力 から暗順底機能を推定する方がやや確からしさが大きいといわれている。

しかし、眼の機能の上からは、視力に関与する視細砲（錐体細胞）と暗順応機能に関与する視 細胞（桿体細胞）とはそれぞれ異つている。従つて両者の間にある程度の相関があるというとと は、視力の良いものの多くは、眼の機能の全体が資質的に優れておら、その結果暗順応機能もよ くなつているということのためではないかと思われる。それ故視力椔查によつて必ずしも暗順応 
機能の良否の判定を行い得るものではないと考劣る。

（2）昼間視力と薄暮視力との間にも関相及係はあるが、照度が低くなるに従つて薄暮視力の個 人差は大きくなり、夜間視力への移行前において最も大きくなる。又昼間視力と夜間視力との間 にも、正常眼においてはある程度の関係があるといわれているが、夜間視力の個人差は少い。

（3）暗順応機能と明順応直後における低照度下の視標の可読時間との関係については、多くの 調查がなされており、今回の調查において実施した結果から侾えても、相互にかなりの相関及係 があるてとがわかる。との場合後者には薄暮或は夜間視力もある程度関係しているものと思われ る。

以上のような点及び今回の調查結果より、航海士の夜間視の適性の問題において最も重要な機 能は暗順応機能と夜間視力であり、それぞれ独立に検查する必要があるのではないかと考える。

次に適性蚞查の方法としては、集団蚞查を行うことが前提となるので、できるだけ短時間に蚞 查を終了しうるものであり、取扱いに容易なものでなければならないが、一応次のような方法が 考光られる。

即ち低照度下における視整の可読時間を測定する方式によつて暗順応機能を評定し、更に視標 にはランドルト氏環或は文字と背景との対此の種々異つたもの危い，それによつて夜間視力の 测定も行うととができるようにする。

現在てのような検査ができるような装置を試作しているが、今後更に其体的な蚞查基準を椎討 する予定である。

最後に夜間視の訓練について簡単に述べる。航海士としては夜間視機能の優れたものを選ぶ必 要があるが、更に訓練によつてその機能を向上させるというととも重要なととである。ての場合 夜間視の訓練というととは、感光物質が増加したり、光化学反応が促進されたりするととはなく 視細胞の解剖学的関係、明度識別閾の低下、刺激反応時間、或は伝達時間の短縮等中枢系にお打 る空間覚の機能の向上に関係すると考えられている。

従つて航海士にとつて、暗順応の諸現象を良くわきま㐬間における周囲の態勢を空間覚的 そ把握する能力を向上させるために、夜間視の訓練を行うということは必要なととである。

米国空軍 ${ }^{(2)}$ においては夜間視訓練装置 (Night Vision Trainer) といつた模擬方式を用いて夜 間視訓練を行つている。装置は日常の戸外に抢ける夜間の景色を夜のように暗いえクリーンに写 す一種の投射機であるが、てれによつて暗順応の諸現象を説明し、叉夜間に物を見るには多くの 練習が必要であるてとを認識させるのを目的としている。

\section{6 む す び}

航海士の夜間視の適性について、海技専門学院の学生 146 名の暗順応機能の調查結果及び従来 の文献にもとずいて蚞討を行つたが、今後更に海難における人的要因に関する事例研究の面に系 口をもとめて、機能の評洒基準及び検䍒の具体的な方法等について研究を進河る予定である。 終りに嗯切なる御教示をいただいた大島正光博士に深く感謝の意を表します。

\section{参 考 支 献}

1) 西部・荒・千原：航海士の夜間視力の保護について・日本航海学会堎第11号

2） 日本眼科全書第 7 巻第 2 冊 $\quad$ p. 258

3）同上 上 220

4）適性検查ハンドブック 労働科学研究形 

5) 日本眼科全書第 7 巻第 2 册 $\quad$ p. 290
6) 黒木武一：桿状体視力の個人差に関する研究 海軍々医会雑誌 8（昭12）
7) 曰田正雄: 薄暮視力の研究 海軍々医会雑誌 32.1 (昭18)
8）山口医大産業医学研究所年報 3 (1955), 4 (1956)
9）航空医学実験隊：夜間視 航空医学資料 -22 